\title{
Kepastian Dan Ketidakpastian Dalam Sains
}

\author{
Harry Firman \\ Departemen Pendidikan Kimia Universitas Pendidikan Indonesia \\ JI. Setiabudi No. 229 Bandung 40154 \\ e-mail: harry firman@upi.edu
}

\begin{abstract}
Artikel ini mengetengahkan hasil kajian filosofis tentang kepastian (certainty) dan ketidakpastian (uncertainty) dalam sains. Kepastian menyumbang pada superioritas sains, sementara ketidakpastian menyumbang pada limitasi sains. Kepastian dalam sains berakar pada epistemologi empiris yang diaplikasikan dalam sains, serta tradisi komunal saintis untuk memelihara obyektifitas dan keuniversalan bagi klaim-klaim sains. Sementara itu ketidakpastian dalam sains berakar pada ketidakpastian metodologis dan ketidakpastian intrinsik dalam struktur pengetahuan sains. Kajian ini secara simultan mewujudkan apresiasi dan skeptisitas terhadap sains.
\end{abstract}

Kata Kunci: Superioritas sains, limitasi sains, kepastian dalam sains, ketidakpastian dalam sains.

\begin{abstract}
This article presents the results of a philosophical study of certainty and uncertainty in science. Certainty contributes to the superiority of science, while uncertainty contributes to the limitation of science. Certainty in science is rooted in empirical epistemology that is applied in science, as well as the communal tradition of scientists to maintain objectivity and universality for scientific claims. Meanwhile uncertainty in science is rooted in methodological uncertainty and intrinsic uncertainty in the structure of scientific knowledge. This study simultaneously manifests appreciation and skepticism towards science.
\end{abstract}

Keywords : Science superiority, science limitation, certainty in science, uncertainty in science

\section{Pendahuluan}

Dari perspektif sejarah secara nyata reputasi sains mengalami fluktuasi. Di era zaman Plato, reputasi sains adalah rendah. Perhatian pada pengalaman inderawi terhadap fenomena alam di sekitar kita kurang populer di masyarakat, karena berada di bawah bayang-bayang pemikiran Plato (424-348 SM) yang menyatakan bahwa alam pada hakikatnya tidak sempurna, hanyalah tiruan/salinan dari realitas absolutnya di dunia ide di keabadian yang tidak dapat dilihat. Lebih lanjut, Plato menyatakan agar mengerti dunia, seseorang harus berkontemplasi prinsip-prinsip umum di sebalik hal-hal yang teramati. Akibat dari pemikiran seperti itu, timbul pandangan bahwa menjadi seorang saintis adalah merupakan suatu kebodohan. Namun murid Plato, yakni Aristoteles (384-322 SM) mengubah persepsi ini. Aristoteles memandang pengetahuan sebagai sesuatu yang berkembang di luar struktur persepsi dan pengalaman, yang membawa semua informasi yang datang ke kita melalui semua indera yang kita miliki. Oleh karenanya kita perlu menelaah fenomena, bukan menjauhinya. Baginya, alam yang diinderanya adalah "realita nyata" (Mannoia, 1980).

Reputasi sains kembali terangkat pada zaman Renaissance di Abad ke-17 berkat karyakarya spektakuler Bacon, Kepler, Galileo dan Newton. Kemajuan dalam matematika pada zaman itu mendorong perkembangan dalam sains. Sains modern lahir di zaman itu, dan sejak itu pertumbuhan sains berlangsung cepat, begitu pula dengan aplikasinya dalam dunia industri. Reputasi sains sangat tinggi pada era itu, sehingga sains dipandang sebagai jawaban terhadap segala macam pertanyaan dan masalah manusia. Akibatnya limitasi sains tidak pernah dikaji, 
tertutupi oleh eforia kemajuan dan kemanfaatannya bagi manusia. Seolah-olah sains tanpa kesalahan.

Label saintifik membawa "majik" kebenaran, obyektivitas, dan kepastian absolut. Produk yang dilabel saintifik dipandang pastilah lebih baik. Dalam rangka mempengaruhi negara untuk meningkatkan anggaran riset sains, Francis Bacon menyatakan bahwa "knowledge is power" (pengetahuan adalah kekuatan), dan sains adalah cara terbaik untuk meraih pengetahuan ini (Bynum, 2012). Fenomena "scientism" muncul pada era itu, yakni suatu doktrin yang menyatakan bahwa hanyalah sains yang dapat memberikan interpretasi yang valid terhadap realita, sehinga metode sains (scientific method) harus digunakan dalam bidang-bidang lain (Okasha, 2016).

Disilusi tentang sains mulai disadari ketika metode ilmiah menemui kegagalan dalam memecahkan masalah-masalah sosial, bahkan menimbulkan masalah baru, seperti kemiskinan sebagai akibat dari kurang terantisipasinya implikasi sosialnya. Di samping itu aplikasi teknologi berbasis sains meningkatkan secara tajam kebutuhan energi, yang bukan hanya menyebabkan masalah energi ansich, melainkan juga berdampak pada pencemaran lingkungan. Memang sains telah melahirkan jenis material baru, khususnya plastik, yang membawa modernisasi pada kehidupan manusia, namun di belakang hari ternyata menggejala dampak lingkungan yang ditimbulkannya, yang mengancam kehidupan di muka Bumi. Begitu juga dengan penemuan dan penggunaan obat-obatan selain manfaatnya, justru memunculkan risiko bagi kesehatan juga.

\section{Metode}

Kajian ini meninjau dengan pendekatan seimbang kepastian dan ketidakpastian dalam sains dari perspektif epistemologi dan ontologi sains. Tinjauan epistemologi meneropong bagaimana metodologi yang diaplikasikan komunitas sains dalam menemukan pengetahuan dan menjaga keobyektifan pengetahuan temuannya. Sementara itu tinjauan ontologi mengkaji hakikat realita yang yang ditelaah dalam sains. Sintesis keduanya mengkungkap baik kepastian dan ketidakpastian dalam sains.

\section{Hasil dan Pembahasan}

\section{Kepastian dalam Sains}

Sains mempunyai keunggulan hanya dalam menjawab jenis terbatas pertanyaanpertanyaan tentang alam, namun tidak dapat mejawab semua hal. Sesungguhnya keberhasilan sains pada Abad ke-17 adalah karena sains meninggalkan pertanyaan mengapa (why) sebagaimana menjadi tumpuan filsafat alam, seraya memfokuskan kajiannya untuk menjawab pertanyaan bagaimana (how). Di samping itu, sains pada era itu berhasil mengkapitalisasi matematika sebagai alat dan menjadikan sains lebih deskriptif daripada spekulatif (Mannoia, 1980). Keduanya proses itu menyumbang pada kredibilitas sains di masyarakat.

Sains memisahkan dirinya dari bentuk pengetahuan lain oleh epistemologi empirisnya. Sumber pengetahuan dalam sains berbeda dari sumber pengetahuan dalam ilmu lain. Sains secara eksklusif hanya berurusan dengan dunia empiris berdasarkan pengalaman inderawi. Pengetahuan sains adalah tentang dunia inderawi, berawal dari pengalaman inderawi, dan teruji terhadap standar-standar pengalaman inderawi juga. Albert Einsten (1879-1955) pernah menyatakan bahwa "sains bermula dari fakta dan berakhir dengan fakta, dan teori menjembatani keduanya" (Suriasumantri, 2009). Sementara IImu lain tidak menggunakan epistemologi empiris tersebut, yang standar kebenarannya bukan pada pengalaman inderawi, melainkan berlandaskan pada sumber-sumber lain seperti wahyu, wibawa, dan intuisi. Filsuf dan matematikawan René Descartes menggunakan intuisinya dalam menimbang gagasan mana yang kebenarannya pasti.

Banyak yang berpandangan bahwa pengetahuan yang berlandaskan pada fakta pengalaman inderawi dan diuji dengan fakta pengalaman inderawi membawa superioritas bagi sains. Namun sesungguhnya ada faktor penguat lainnya yang kontributif pada superioritas sains, yakni obyektifitas klaim-klaim dalam sains. Terdapat dua faktor yang dipandang membawa sifat obyektif bagi sains, yakni keterujian antarsubyektif (inter-subjective testability), dan keuniversalan (universality). Secara simultan kedua faktor ini memberikan sains sekaligus keatraktifan dan kekuatan. Obyektifitas dalam sains dicapai karena sains mengekslusikan keterlibatan personal dan opini-opini yang dapat menjadi sumber subyektifitas ilmuwan. 
Obyektifitas dan subyektifitas sesungguhnya perlu dipandang sebagai suatu kontinum, yang memposisikan obyektifitas dan subyektifitas di kedua kutub berlawanan pada kontinum tersebut. Sampai derajat tertentu saintis menggunakan subyektifitasnya, khususnya dalam menginterpretasi fakta yang diamatinya. Tidak dapat dipungkiri bahwa imajinasi saintis (melibatkan subyektivitas) acapkali berperan dalam penemuan ilmiah (scientific discovery). Bekerjanya imajinasi dalam kompleksitas proses penemuan ilmiah diungkapkan Albert Einsten dalam pernyataannya: "No path leads from observation to the birth of a theory" (Mannoia, 1980). Namun, saintis mempunyai tradisi bekerja dengan prinsip komunal (Suriasumantri, 2009). Prinsip ini menuntut pengetahun ilmiah harus menjadi pengetahuan publik sehingga hasil riset harus dipublikasi, harus ada kebebasan untuk bertukar informasi ilmiah antar saintis di mana pun, dan saintis harus bertangungjawab kepada masyarakat ilmuwan akan kredibilitas karya yang dipublikasinya.

Perwujudan dari prinsip komunal komunitas saintis ini memungkinkan temuan individual seorang saintis secara terbuka dikaji dan diverifikasi oleh anggota lain dalam komunitas. Keterujian inter-subyektif menentukan kredibilitas pengetahuan yang ditemukan atau digagas seorang saintis. Semua pengetahuan mesti mengandung subyektifitas personal, namun keterlibatan komunitas menjadi filter bagi ideosinkratik personal para saintis (Okasha, 2016). Jadi, sains mengadung elemen personal, namun keterlibatan komunitas menyebabkan terpeliharanya obyektivitas sains itu sendiri.

\section{Ketidakpastian dalam Sains}

Di samping kepastian yang dimiliki sains sebagaimana dipaparkan di muka, sains pun punya ketidakpastian yang menyumbang pada limitasi sains itu sendiri. Ketidakpastian sains berpangkal pada dua sebab, yakni: (1) Ketidakpastian metodologis, yakni ketidakpastian yang muncul karena cara bagaimana gagasan saintifik terbentuk; dan (2) Ketidakpastian intrinsik, yakni ketidakpastian yang muncul karena hakikat dari gagasan saintifik itu sendiri (Mannoia, 1980).

Ketidakpastian metodologis terjadi karena dua sebab, yakni sesatan (error) dan metode konfirmasi. Sesatan pada proses penyelidikan dalam sains terjadi sebagai akibat dari kesalahan indera manusia ketika melakukan observasi dan pengukuran karena kelelahan dan kelengahan. Akibatnya observasi langsung tidak sepenuhnya akurat. Walaupun observasi dan pengukuran lebih banyak dilakukan dengan instrumentasi canggih dan presisi, namun sesatan selalu saja ada. Sesatan dalam observasi dan pengukuran ini mempengaruhi hukum atau teori yang dikonstruksi berdasarkan data hasil observasi tadi.

Sumber ketidakpastian kedua terletak pada proses konfirmasi terhadap teori yang digagas saintis. Dalam metode ilmiah, deduksi atas suatu teori menghasilkan prediksi-prediksi, dan selanjutnya prediksi-prediksi tersebut dikonfirmasi melalui eksperimen dan observasi, serta generalisasi ditarik secara induktif. Sebagaimana telah dikemukakan sebelumnya, kritik David Hume (1711-1776) terhadap proses induksi itu selalu tidak lengkap, karena hanya berdasarkan pada konfirmasi dari sebagian kecil kasus yang diamati (Southwell, 2013). Sekalipun konfirmasi eksperimental dilakukan secara terus menerus dengan data yang lebih banyak, mesti saja tidak akan meliput fenomena yang akan datang yang belum ditemukan saat ini. Tidak ada jaminan hal yang terjadi esok hari akan sama dengan yang terjadi hari ini. Jadi, konfirmasi akan selalu meninggalkan kasus-kasus yang tidak terselidik (unexamined cases). Cacat dalam proses konfirmasi menyumbang ketidakpastian pada teori yang dikonstruksi. Oleh sebab itu konfirmasi atas prediksi-prediksi teori harus menjadi proses yang tak-berakhir (never ending process) dalam dunia sains. Untuk mengatasi kasus yang tak terselidik itu, perlu asumsi uniformitas alam (uniformity of nature), yaitu bahwa fenomena yang diselidiki sama di mana saja berada dan kapan saja terjadi, misalnya natrium klorida mempunyai struktur kristal dan sifat-sifat yang sama dimana saja zat itu berada dan dengan cara apa zat itu dibuat.

Jenis lain ketidakpastian dalam sains dinamakan ketidakpastian intrinsik, yaitu ketidakpastian yang berakar pada struktur dan penggunaan gagasan ilmiah. Pertama, dalam kenyataannya banyak pengetahuan ilmiah bersifat statistik (Manoia, 1980). Sebagai ilustrasi, dalam fisika dan kimia ada hukum waktu paro $\left(t_{1 / 2}\right)$ yang menggambarkan laju peluruhan unsur radioaktif. Jika waktu paro adalah 10 menit dan sekarang terdapat 500.000 atom, 10 menit berikutnya akan hanya ada 250.000 atom, dst. Hukum ini berlaku jika diaplikasikan pada jumlah besar atom, namun akan menimbulkan ketidakpastian dalam memprediksi bilamana atom radioaktif individual akan meluruh. Contoh lain, andaikan Biro statistik suatu daerah mengumumkan bahwa rata-rata keluarga di daerah itu mempunyai 2,3 anak, adalah nyata 
bahwa tidak ada keluarga yang mempunyai 2,3 anak. Hukum statistik membawa ketidakpastian pada kasus individual.

Ketidakpastian intrinsik lainnya diilustrasikan oleh ketidakpastian Heisenberg (uncertainty principle). Sebagai konsekuensi dari temuan elektron sebagai partikel dan gelombang (waveparticle duality), Werner Heisenberg (1901-1976, penerima Hadiah Nobel tahun 1932) menyatakan bahwa kita bisa tahu momentum suatu elektron, atau posisinya, tetapi tidak keduaduanya secara simultan dengan presisi yang tinggi (Bynum, 2012). Jika kita mengetahui secara pasti momentum suatu elektron dengan tepat maka pada saat yang sama kita tidak dapat mengetahui posisinya secara pasti. Sebaliknya, jika kita mengetahui secara pasti posisi elektron, momentumnya tidak diketahui secara pasti. Pemikirannya itu yang dinamakan prinsip ketidakpastian Heisenberg yang digagas untuk menjelaskan perilaku partikel sub-atom, seperti halnya elektron. Sebagai konsekuensi dari prinsip tersebut ialah lokasi elektron dalam atom tidak dapat dipastikan, kita hanya dapat mengatakan terdapat probabilitas menemukan elektron di daerah tertentu di seputar inti atom.

\section{Kesimpulan}

Kepastian dan ketidakastian merupakan elemen yang inheren dalam sains. Kepastian dalam sains berpangkal dari epistemologi empiris yang diplikasikan dalam sains yang menjamin korespondensi teori dan fakta empiris, serta aktivitas komunitas saintis yang terbuka bagi verifikasi-verifikasi yang menyebabkan terpeliharanya obyektifitas dalam sains. Sementara itu, ketidakpastian dalam sains berpangkal dari proses verifikasi yang tidak akan lengkap, dan karakter pengetahuan yang bersifat statistik serta ketidakpastian intrinsik yang dalam fenomena yang dikaji dalam sains.

\section{Daftar Pustaka}

Bynum, W. (2012). A little history of science. London: Yale University Press.

Mannoia, V. J. (1980). What is science?: An introduction to the structure and methodology of science. Lenham, MD: University Press of America.

Okasha, S. (2016). Philosophy of science: A very short introduction. Oxford: Oxford University Press.

Southwell, G. (2013). The 50 philosophy of science ideas you really need to know. London: Quercus.

Suriasumantri, J. S. (2009). Filsafat ilmu: Sebuah pengantar popular. Jakarta: Pustaka Sinar Harapan. 